\title{
Discerning Skills: Psychological Insight at the Core of Jesuit Identity
}

\section{Cristiano Casalini}

The ability to examine talents is one of the key features that continue to distinguish the Jesuits in a large number of fields today. The mission statements of many educative institutions run by the Society all around the world, such as schools and universities, insist on the cultivation of students' skills and talents as a hallmark of their excellence. Yet, this characteristic goes beyond the boundaries of the ministry of education, for it involves many other tenets of the Jesuit identity.

The Society adopted this key feature of its program during the first fifty years of the order's inception, as discerning individuals' cognitive skills became a crucial problem of survival since the quality of recruitment, the functioning of the entire organizational body, and success in such competitive settings as courts, missions, and, of course, educational institutions, all depended upon this ability.

The multifaceted variety of the ministries in which the Jesuits were involved required the recruiters to foresee which particular field an individual could be entrusted to and do well, but, as superiors general of the order, Ignatius of Loyola (c.1491-1556) and his successors, felt they could not rely only upon the whimsical impressions of superiors, who were to recruit and form people all around the world. Therefore, they searched for a method that could be applied scientifically and consistently in all of the Society's tasks. Curiously, it was sixteenth-century Galenic culture that provided the Society with this method. Humanistic studies had revived the interest of scholars in Galen's large corpus of works, and, during the first half of the sixteenth century, Galen (c.129-200) emerged as the major authority on medicine in European universities, replacing Avicenna (980-1037). The discovery of Galen's texts had important repercussions for psychology, since one of his works that emerged from the darkness, Quod animi mores temperamenta sequantur (That men's behaviors depend on their temperaments), posed a connection between mind and body quite different from the one held by the brand of Aristotelian philosophy traditionally accepted in universities. This work provided the European common sense, which from the Middle Ages had relied upon the presumption of a connection between one's bodily appearance and character, with a scientific and coherent

(C) CRISTIANO CASALINI, 2016 | DOI 10.1163/9789004313354_012

This is an open access chapter distributed under the terms of the Creative Commons Attribution-

Noncommercial-NonDerivative 3.o Unported (CC-BY-NC-ND 3.0) License. 
theory about how to predict behavior based on the empirical observation of skin color and other external signs of the humor that prevailed in the body and determined a person's particular temperament.

It should not come as a surprise that the Jesuits, being men of their time, had foreseen the possible practical applications of the scientific method suggested by Galen in this work. Furthermore, Ignatian spirituality, as it emerges from the Spiritual Exercises, affirmed the idea of psychosomatic unity as the fundamental lens through which to examine the individual. A scientific theory that could explain at least in part the connection between body and soul was therefore compelling for the Jesuits within their spiritual culture.

Yet, Galen's theory about humors and temperaments did not provide a clear statement as to whether and how a temperament could determine someone's talent. Juan Huarte de San Juan (1529-88), a Spanish physician influenced by the sixteenth-century Galenic renaissance, filled this gap by publishing the Examen de ingenios (The examination of talents) in 1575. He blended Galen's theory of humors with the Aristotelian tripartition of the mind's faculties in order to demonstrate how humors and temperaments determine skills. Applying Huarte's method, one was supposed to be able to discern the talent of someone else by inquiring into his temperament and, more basically, his bodily appearance.

Huarte's work stands as a turning point in the Jesuit habit of inquiring into an individual's talent. Prior to the appearance of the Examination of Talents, the documents published by the Jesuits which discussed recruitment had emphasized the need for the superiors to recognize the kind of skills an individual was endowed with, whether he be a young man on probation or an old fellow. But they did not specify how to link behaviors and temperaments with faculties of the mind. Even the catalogs, which had to be compiled by provincials precisely to communicate this kind of information to Rome, had lacked a list of criteria to describe the fellows' talents.

With the publication of Huarte's work, everything changed. Although the Society's official documents did not explicitly mention the name of this Spanish physician, his ideas nevertheless had a clear influence on the Jesuit way of proceeding in examining talents in the period that followed. The catalogs began to be filled following Huarte's proposed connection between particular temperaments and their related skills, as is revealed by the tasks that the superiors suggested their fellows should be entrusted with.

An entire Jesuit literature immediately sprouted around this issue of human talents. The first case we see is of Antonio Possevino (1533-1611), who devoted the introduction of his famous Bibliotheca selecta (1593) to the cultivation of talents, declaring that he generally accepted the tenets of Huarte's theory, but 
with the extremely important exception of freewill, which Huarte had denied. Antonio Zara (1574-1621) did the same in his renowned Anatomia ingeniorum (1615). More importantly, a consistent and persistent adoption of the schemes of correspondence between temperaments and skills as proposed by Huarte is testified in several Jesuit writings throughout the centuries until the suppression of the order in 1773 .

The aim of this chapter is to explore the influence of Huarte's method on the Jesuits and the ways in which the order sought to apply his ideas in practice. In the first part, I will address the issue of the Jesuits' historical sensitivity to the question of human talents, beginning with the Society's concern about recruitment and organization. By comparing the official documents of the Society with the customs of other religious orders, the particular concern of the Jesuits for discerning aspirants' talents will emerge as predominant in the process of recruitment. A survey on the adoption of the habit of filling the so-called secret catalogs, a practice unique to the Society in the sixteenth century, will reveal how important the publication of Huarte's Examination of Talents was to the Jesuits. A reading of some of the Roman College's catalogs (1600) compiled after this work first appeared and now conserved at the Archivum Romanum Societatis Iesu will then provide the reader with an example of the Jesuit application of Huarte's ideas.

The Jesuits became so deeply involved in Huartian culture that they applied its method even in ministries that connected the order with lay people, particularly in the case of education. I will describe the development of this application in the second part of the chapter, taking the Ratio studiorum (1599) as an example that prominently reveals the extent to which the publication of the Examination of Talents shaped the Jesuit way of examining students' talents.

The Jesuit reception of Huarte's masterpiece triggered a debate within the order, as testified by the Jesuit literature mentioned above, and this is the focus of the final part of the chapter. This survey will also show that Huartian ideas were so deeply rooted in the Jesuit culture that they were able to reemergeeven within a different scientific context-after the restoration of the order in 1814 .

\section{Recruitment and Governance}

Although Ignatius of Loyola had shaped the Jesuits' organization in the same mold as the medieval mendicant orders - he divided the Society into provinces governed by a superior, and so forth — many features of the institute were 
distinct from the traditions of both the Franciscans and the Dominicans. ${ }^{1}$ Standing out among these features, which even included some scandalous omissions for a so-called religious order (such as the collective choir), were the rules pertaining to recruitment.

Concerning this issue, the Constitutions insisted that those who sought to be admitted to the order should be examined for certain psychosomatic features. To be admitted in probation, a candidate had to be endowed with an honorable physical appearance as well as with the gifts needed in order to be useful in helping souls. These gifts were detailed with respect to the mind's faculties, namely intellect, memory, and will, as well as to exterior outlook-that is, pleasant manner of speech, honorable appearance, health, and strength of the body.

The Jesuit order stressed the importance of psychosomatic unity far more than the medieval orders, and a defect in one of these characteristics could even be a reason for non-admittance to the Society. For example, the Capuchins, an order born a few years before the Jesuits (1528), did not focus on the issue of human gifts as a vital requirement for admittance. Although they shared with the Jesuits the same concern about the fast growth of their order-both believed that reckless recruitment was the basis of the medieval orders' troubles - they did not mention any criteria for somebody's admittance other than a true and deep desire for living in poverty:

We desire that our congregation grow much more in virtue, perfection and spirit rather than in numbers and we know that as the infallible truth said, "Many are called but few are chosen." And the Seraphic Father said when close to death, "Nothing harms the pure observance of the Rule as much as a multitude of useless, carnal and brutish friars." Hence we instruct the Vicars to diligently examine their circumstances and quality and not receive those who do not demonstrate that they have the best intention and a most fervent will.

Furthermore, so as to not attract attention and to avoid all scandal we forbid the reception of those who have not completed their sixteenth year, or who still have a child-like face if they have passed the sixteenth year, so that they know from experience what they are promising. ${ }^{2}$

1 See, for example, Markus Friedrich, Der lange Arm Roms?: Globale Verwaltung und Kommunikation im Jesuitenorden 1540-1773 (Frankfurt: Campus, 2011).

2 The Capuchin Constitutions of 1536: A New Translation in English, trans. Paul Hanbridge (Rome: Collegio San Lorenzo da Brindisi, 2007), 5. 
The Jesuit emphasis on the importance of talents in the candidates has long been regarded as one of the order's defining features. The renowned French novelist Honoré de Balzac (1799-1850), for instance, who was seeking to provide a fair account of the Society's history in a period hostile to the Jesuits, recognized this attitude as being one of the major reasons for the Jesuits' success:

In these seminars they used to inquire into the aspirants' qualities, as well as into their knowledge; skillful masters took care of novices' talents, according to each one's character, so therefore they could report to the Society on the commitment more suitable for each one. Since they led public education, they sent to their house of novitiate only the best, the most active, and most remarkable youth, whom they picked from a crowd of aspirants. [...] When one had been evaluated, he was destined to shine in the field where his now-understood vocation called him. ${ }^{3}$

For Balzac, the examination of a candidate's mental gifts by the Jesuit superiors was just the first step of a life of similar psychological examinations. Inquiring into a Jesuit's skills in fact became a frequent occupation of the superiors, who methodically took notes and reported their observations in the catalogs they were required to send regularly to Rome.

The practice of cataloging members was not an absolute novelty among religious orders. The Benedictine monks, for example, used to keep catalogs (sometimes called "registra," sometimes "cartularia") of their members, as did Franciscans and Dominicans. Yet the Jesuits differed from the other orders in their efforts to modernize this practice by introducing a range of new items to be reported in the catalogs; in so doing, they sought to ensure that Rome retained control of the order while identifying the roles to which its members were most suited.

The duty of keeping catalogs is mentioned in the eighth part of the Constitutions:

3 “C'était dans ces espèces de séminaires que l'on étudiait les qualités des aspirants, leur savoir; d'habiles maîtres s'occupaient, d'après le caractère, les talents de chaque novice, à indiquer à la Société l'emploi que l'on pouvait faire. Comme il y avait une foule d'aspirants, et que les Pères étaient en possession de l'enseignement public, ils n'envoyaient à leur maisons de noviciat que les jeunes gens les plus distingués, les plus actifs, les plus remarquable dans leur études. [...] Lorsque que chacun avait été apprécié, on le destinait à briller dans la partie à laquelle l'appelait sa vocation reconnue." Honoré de Balzac, Historie impartiale des Jesuits (Paris: Calmann Lévy, 1880), 55 . 
For fuller knowledge of everyone, every four months the provincial should be sent, from each house and college, a brief list [brevis catalogus] in duplicate of all who are in the house, and of those who are now missing because of death or some other cause, from the time of the last list sent until the date of the present one, with a brief account of the qualities [dotes] of these persons. In the same manner, every four months the provincial will send to the general the copies of the lists from each house and college. For in this way it will be possible to have more information about the persons and to govern the whole body of the Society better, for the glory of God our Lord. ${ }^{4}$

The frequency with which the catalogs originally had to be compiled probably reflected the frequency with which data on personnel needed to be updated in an age when the mortality rate was high. Yet this also created difficulties, as superiors needed to assess each member's qualities and fill the catalogs several times a year. The order therefore responded to this problem in decree 48 of the Second General Congregation (Chapter II), which offered some relief to the superiors by stipulating that the catalogs should only be updated on an annual basis.

The same congregation established the Formula scribendi (How the Jesuits should write), a style guide for writing official documents or composing formal correspondence with the curia, which devoted a chapter to describing how to fill out an annual catalog. 5 This chapter is extremely important for understanding the way in which the Jesuits differed from the other orders. The Formula divides the annual catalogs into three different parts, each one with a specific information goal. The first listed the names of the Jesuits who were present in a house or in a college, and additional personal data consisting of list number, place of birth, age, strength (vires), date of admission, studies completed, ministries performed, teaching degree, and position in the Society. Another part provided some economic information about the house or the college and a list of both novices and deceased members.

The last part, which was actually numbered as the second one, was called Catalogus secretus and is the most relevant for this discussion. It was called secretus because it did not list the Jesuits by name but reported only the listing number provided in the first catalog. This measure was meant to ensure that anyone peering into or stealing the catalog could not discover the superior's

4 The Constitutions of the Society of Jesus and Their Complementary Notes (St. Louis: The Institute of Jesuit Sources, 1996), 328.

5 Institutum Societatis Iesu (Florence: Ex Typographia a SS. Conceptione, 1893), 3:45. 
opinion about and evaluation of a particular member. The secret catalog was actually a schematized evaluation of every Jesuit. The evaluation also reflected the active role played by the superior, as he suggested the kind of role within the Society a Jesuit could be entrusted with. The template for this evaluation form lists qualities that can easily be recognized as the major distinctive features of Jesuit identity.

The Formula specifies that this catalog was to be filled out in the following way:

Skills and qualities of each one should be described in the second catalogue, that is: talent, judgment, practical wisdom, practical experience, advancement in arts, physical appearance, and particular skills for performing the Society's ministries. ${ }^{6}$

While there was a clear rationale for collecting information on the literary advancement of each member since the Society had thrown itself into the challenge of running colleges and engaging in the world of universities, the Formula also required other information to be collected about the character and general health of the order's members. As we saw above, the Jesuits preferred to admit new members who possessed an honorable appearance, mostly out of social concern. Such an appearance could be an important factor for improving someone's appeal: according to the tradition of rhetoric, which traced back to Cicero (106-43 вСЕ) and Quintilian (c.35-c.100), the body had a crucial impact on a person's eloquence.

However, an honorable appearance was also important for reasons beyond enabling the Jesuits to integrate with the communities in which they worked. The renaissance of Galenism in sixteenth-century medicine, as well as humanistic culture, had spread a common belief in the idea that the appearance of the body reflected the qualities of the soul. Galenists not only believed that the body revealed men's morality, as was intended by the proverb mens sana in corpore sano (a sound mind in a sound body), but also held that a person's appearance revealed the qualities of his character. This was mostly due to Galen's theory of humors, according to which every man was naturally endowed with an unbalanced temperament, meaning that one of the four humors prevailed in the body over the other three. The prevalence of a humor had repercussions on a person's character as well as their physical appearance.

6 "In secundo catalogo dotes et qualitates uniuscuiusque describantur, videlicet: ingenium, iudicium, prudentia, experientia rerum, profectus in litteris, naturalis complexio, et ad quae Societatis ministeria talentum habeat," ibid. 
Most of the success of Giovanni Battista Della Porta (1535-1615) and other physiognomists was due to the renaissance of Galen's theory.7

In 1575, Juan Huarte de San Juan, an obscure Spanish physician who died in poverty, published a book entitled the Examen de ingenios which immediately became a bestseller all over Europe. ${ }^{8}$ In this book, he extended Galen's theory of humors to men's cognitive functions, inaugurating a new branch of psychology and triggering a debate on men's temperaments and skills that endured until the nineteenth century, as even Francis Galton (1822-1911), a half-cousin of Charles Darwin (1809-82) and author of Hereditary Genius (1869), frequently cited Huarte in his works. Huarte applied the theory of the temperaments to traditional Greek psychology by asserting that the body influenced the operations of the mind. Hence, according to him, the prevalence of a humor could foster some specific faculties of the mind while hindering others. By doing so, Huarte provided a scientific method to discern people's specific skills, which he called ingenium.

In the sixteenth century, common people used the term ingenium (talent) in a loose sense, meaning a sort of creative intellectual power. On the one hand, it meant the same as the word "wit" in current English: a smart, clever, but also sharp and quick-witted person. On the other, ingenium meant the creative power that Romanticism would have called genius (in Latin "genius," "ingenium"). Ambrogio Calepino's (1435-1511) popular dictionary traced the term ingenium back to the Latin verb "generare" (to engender). According to the art of rhetoric, ingenium referred to the rhetorician's ability to find witty topoi for his speech, ${ }^{9}$ and humanists such as Erasmus (1466/69-1536) and Juan Luis Vives (1492-1540) used it to mean a fortunately gifted man of culture. Huarte broke with this tradition, which had generally used talent solely as a term of praise, by stating that talent was a scientific subject with useful social applications. The point of this science was not to determine how great or small someone's talent was, but rather which kind of talent someone was endowed

7 Giovanni Battista Della Porta, De humana physiognomonia (Vico Equense: Giuseppe Cacchi, 1586).

8 Juan Huarte de San Juan, Examen de ingenios, para las sciencias: Donde se muestra la differencia de habilidades que ay en los hombres, y el genero de letras que a cada vno responde en particular; es obra donde el que leyere con attencion hallara la manera de su ingenio, y sabra escoger la sciencia en que mas ha de aprouechar, y si por ve[n]tura la vuiere ya professado, entendera si atino ala que pedia su habilidad natural (Baeza: Juan Baptista de Montoya, 1575).

9 Even the Jesuit authors of manuals of rhetoric would often recur to this meaning. See, for instance, Cypriano Soares, De arte rhetorica libri tres: Ex Aristotele Cicerone \& Quinctiliano praecipue deprompti (Venice: Apud Michaelem Tramezinum, 1569). 
with, so that the state could lead everyone to do the job in which they would perform best.

What Huarte did in his masterpiece was to apply Galen's temperamental doctrine to the Aristotelian rational psychology in order to classify human talents on the basis of the natural mis-temper of man. At the very beginning of the Examen, Huarte mentions Galen's booklet, Quod animi mores corporis temperatura sequantur (That the qualities of the mind depend on the temperament of the body), as the main source of his work. He states that Galen had paved the way for him by determining which kind of temperament corresponds to each kind of human behavior. In the sixteenth-century academy, this work entered a kind of no-man's-land as it was considered less medical than philosophical, and not philosophical enough to be read in the classroom. Thus, it was generally neglected by physicians and teachers of medicine, who preferred to read Galen's greater works on plagues, anatomy, and so forth, rather than to linger on philosophical issues. ${ }^{10}$ And it was also neglected by philosophers, who usually referred themselves to Galen only to confute the theory according to which human souls coincide with the body's temperament.

What Galen states in his booklet is that, just as the body and the soul are tightly connected, the temperament of a body also determines one's character. According to this theory, temperaments were either choleric or bilious (the yellow bile was also called choler), melancholic (in Greek, black bile), sanguine, or phlegmatic. Each temperament makes men inclined to specific moral actions.

Galen's theory was one of strict determinism, and his materialistic view (at this point in his works, although elsewhere he is contradictory) provided a unique problem to Christian anthropology. If the body affects the soul, in philosophical terms this means that matter affects the form; therefore, the form is nothing but material. Men's souls are material: they cannot rise up.

But this was a matter that centuries of Scholastic disputations, founded as they were on a Christianized Aristotle, had already learned to deal with and, perhaps, even settled. The more problematic issue was Galen's strict determinism once the Protestant Reformation had spread, as it was founded on the theory of predestination (which we can consider as a sort of theological

10 José M. López Piñero and Francisca Bujosa Pomar, “Tradición y renovación en la medicina española del siglo XVI," Asclepio 30-31 (1978-79): 285-307. Ana I. Martín Ferreira, El humanismo médico en la Universidad de Alcalá (siglo XVI) (Alcalá de Henares: Universidad de Alcalá de Henares, 1995); Luis García Ballester, "Galenismo y enseñanza médica en la Universidad de Salamanca del siglo xv," Dynamis: Acta hispanica ad medicinae scientiarumque historiam illustrandam 20 (2000): 209-47. 
determinism). Stating that one's actions in life are determined by one's natural temperament is the same as stating that one's actions in life are determined by God (as he is the creator).

Therefore, when Juan Huarte wrote the Examen de ingenios, he went beyond the Galenic tradition, stating that temperament not only affects someone's moral actions but also determines their wit. Indeed, according to Platonic and Aristotelian psychology, there are three rational faculties of the soul: intellect, imagination, and memory. Even if Aristotle did not seem to believe that the body could affect the soul in any way, because matter and form are two separate aspects of the synolon (the composite of matter and form which is the substance, according to Aristotle), Huarte used Aristotle's psychology to complete Galen's theory of the temperaments. Essentially, he thought that the intellect works better in dry conditions while the imagination works better in hot conditions, whereas memory, which was usually depicted as a sponge that retains images (in Latin, species impressae), needs cold and humid conditions. ${ }^{11}$

In this way, Galenic determinism was radicalized: the character of men is not only determined by nature but also by their rational faculties. Hence the choices a man has to make in life are predetermined by his biology, and, perhaps most shockingly, could even be predicted by a good physician who has read the Examen.

Despite the Inquisition's ban on the Examen's first edition (it had to be corrected because its strict determinism seemed to entail the Protestant doctrine of predestination), the Jesuits read it very carefully and, more importantly, accepted the core of its theory. Two pieces of evidence support this view: (1) the Society introduced the concept of ingenium (talent) in the Formula scribendi exactly five years after the Examen's first edition, during a congregation in which Possevino, the Society's secretary under the former superior general Everard Mercurian (1514-80), was still influential; and (2) the Jesuits, from the publication of Possevino's De cultura ingeniorum (1593) down through the centuries, ${ }^{12}$ were among the most fervent to write about the ways in which talents and skills could be discerned and cultivated.

11 On the concept of species and the problem of human knowledge, see Leen Spruit, Species intelligibilis: From Perception to Knowledge, vol. 2: Renaissance Controversies, Later Scholasticism and the Elimination of the Intelligible Species in Modern Philosophy (Leiden: Brill, 1995).

12 Possevino published the Italian version of this book five years later: Antonio Possevino, Coltura degl'ingegni nella quale si mostrano doni che negl'ingegni dell'huomo ha posto Iddio (Vicenza: Giorgio Greco, 1598). 
How could a religious order adopt a theory which was far more materialistic than religiously oriented, as the Inquisition claimed? The Jesuit literature on talents often refers to two passages of the New Testament in order to interpret Huarte's doctrine as a safe and pious psychology, the first being the parable of the talents and the second Saint Paul's first letter to the Corinthians. These passages endorsed the theory of differences among human beings, for they coherently claimed that God has given everyone different spiritual gifts in order to accomplish his plan for this world. According to the Jesuits, who took Saint Thomas's doctrine of the concord between grace and nature seriously on this point, this meant that everyone's nature had to be different with respect to both the body and soul's operations. Given the safety of this doctrine, they felt they had finally found a method both scientific and religious that they could use to discern human skills.

It is a testament to the superiors' passionate engagement with the task of filling catalogs with assessments of people's talents that Superior General Claudio Acquaviva (1543-1615) had to write to all of them in 1589 to complain that while the central archive was full of personnel catalogs, too few catalogs of properties and economic reports had been sent. ${ }^{13}$

The practice of producing triannual catalogs continued until the suppression of the order in 1773 with no changes worth mentioning (after the restoration in 1814, annual catalogs became the norm). The Jesuits began to print their catalogs during the eighteenth century, but they continued to use the Galenic temperamental theory just as they had in the sixteenth century. Why were the triannual catalogs dismissed after the restoration? Does this mean that the Jesuits abandoned the practice of evaluating members' skills? It is quite likely that what happened after the restoration was simply due to the phasing out of Galenic culture as a scientific doctrine. After the scientific revolution, Galen's theory of humors was discarded as a "non-scientific" corpus of odd ideas. Yet it was so deeply rooted in Western culture that it continued to be used in daily life to describe people and their characters. Hence, while the Jesuits continued to inquire into their people's skills, they did not need to document them using Galen's proper lexicon, as it was no longer a scientific language.

A few examples from the holdings of the Archivum Romanum can help one to understand what this lexicon actually was, and how the superiors evaluated the Jesuits they had to govern. To that end, I will consider some cases from a Collegium Romanum catalog from May $1600 .{ }^{14}$ The catalog was presumably

\footnotetext{
13 Institutum Societatis Iesu, 3:309.

14 ARSI, Rom. 54, fols. 11, 125. Reproductions of these two documents are authorized by the Archivum Romanum Societatis Iesu, to which the author is grateful.
} 
filled out by the rector at that time, Benedetto Giustiniani (1551-1622). The first part (Fig. 10.1) is nothing but a table, and it strictly reflects the rules of the Formula scribendi. The top row lists the following items: name and surname, country of origin, age, health, date of admission, studies completed, degree held, roles in the Society, and professed or coadjutor.

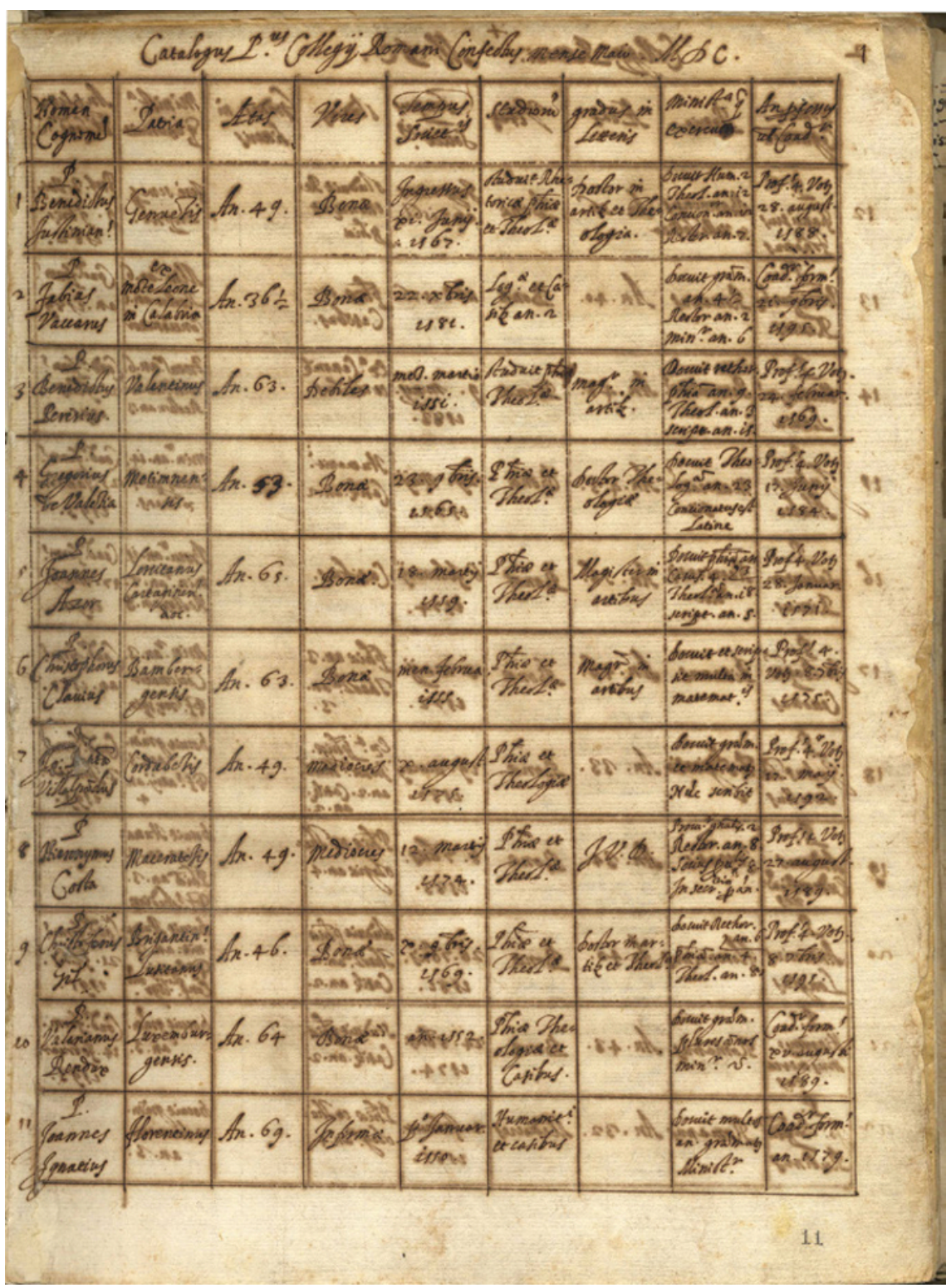

FIGURE. 10.1 The first page of the Triennial Catalogue of the Roman College, 1600 FROM ARCHIVUM ROMANUM SOCIETATIS IESU, ROM. 54, F. 11 
Let us examine the cases of Fabius Vaccarus (listed as no. 2), Benet (Benito, Benedict) Perera (1535-1610) (no. 3), Juan Azor (1535-1603) (no. 5), and Cristovão Gil (1552-1608) (no. 9). While Perera and Azor, renowned scholars of the Collegium Romanum, were sixty-three years old when the catalog was filled out, Vaccarus (thirty-six) and Gil (forty-six) were younger. Perera seemed to have been the weakest among them, since the other three were described as being in good health. While Vaccarus had studied only logic and psychology and did not hold a degree, the others had completed both philosophical and theological studies and held the degree of Magister in artibus (Master of arts). Thus, Vaccarus had only been taught grammar for four years and rhetoric for two, while the others had also been taught philosophy and theology.

In Figure 10.2, their names disappear, as the superior referred to them only by their ranking number. Vaccarus was described as having nothing more than a proficient talent, even though his ability to discern and his experiences were more than ordinary, while his cultural advancement was less than proficient. His temperament, meanwhile, was described as both choleric and melancholic, and this was why his superior considered him barely able to govern $(\mathrm{ad}$ gubernandum) and, particularly, to hear confessions.

Perera was an elderly and highly regarded philosopher. Thus it should not be surprising that his talent was described as "great." His ability to discern was excellent, and his prudence better than ordinary. His advancement in studies was of course extraordinary, while his temperament was moderate, with an inclination toward choleric mistemper. His old age meant he was best suited to the task of writing.

Azor appears to have been one of the superior's favorites. He was described as nothing less than excellent and extraordinary with a mixed temperament that revealed a good but also strong character: he was choleric and sanguine, but in such a way that he was not very far from the perfect moderate temperament. Every task was suitable for him.

In contrast, the superior thought that Cristovão Gil was apt only to do practical things. He was of lively choleric temperament but, according to the superior, was less than proficient in omnibus (i.e., in the skills required for teaching and studying). He was suitable for practical tasks or for confessing and catechizing. In the same catalog, other Jesuits, such as the famous scientist Christopher Clavius (1538-1612), were named in the first part but not described in the second.

As can be seen, choleric was the best temperament for teaching, even though an excess of liveliness could be negative in the eyes of the rector. This was probably due to the difficulty of governing such a temperament, which is 


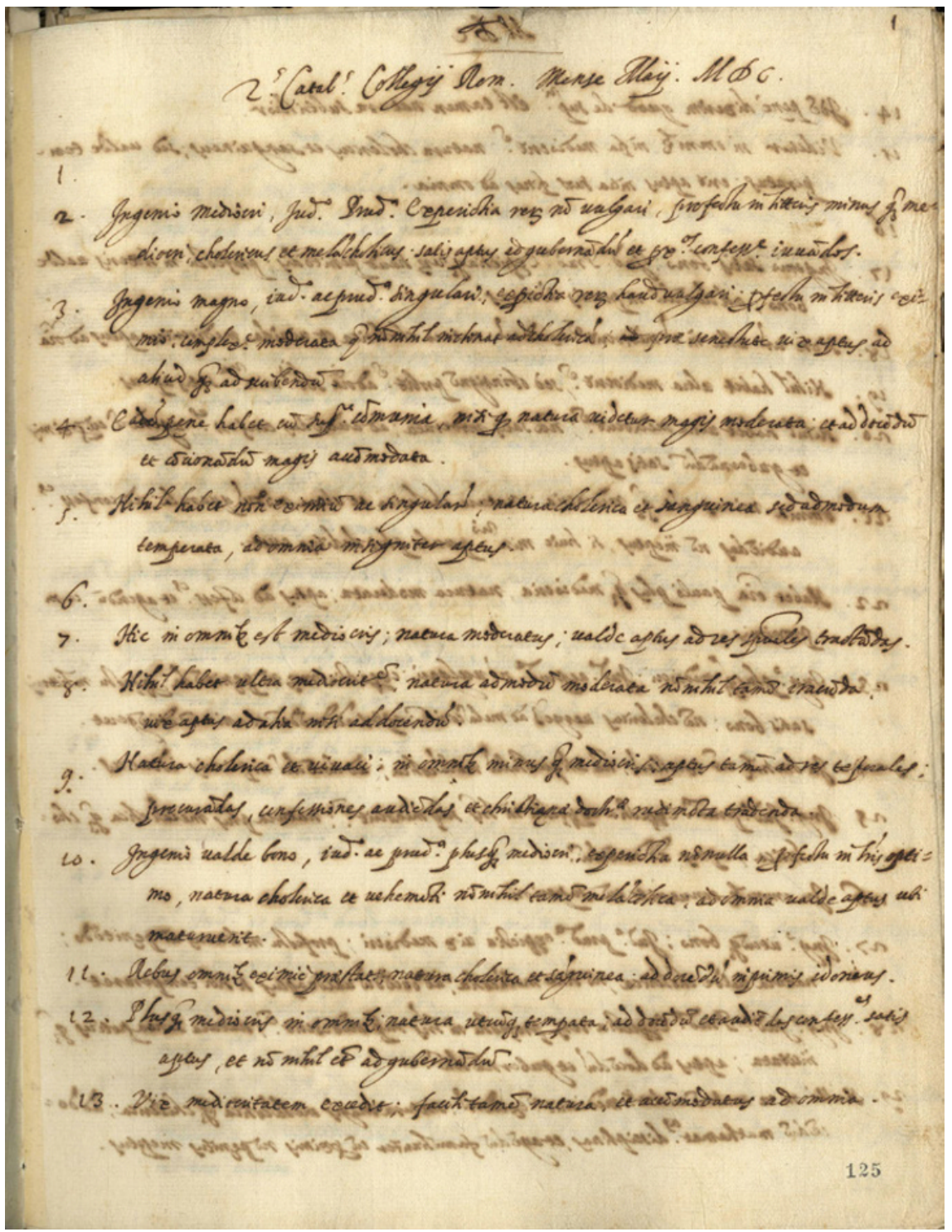

FIGURE. 10.2 An excerpt from the Secret Catalogue of the Roman College, 1600 FROM ARCHIVUM ROMANUM SOCIETATIS IESU, ROM. 54, F. 125

why Giustiniani suggested removing Gil from the studies in which he would paradoxically achieve a great deal of acclaim..$^{15}$

15 The wide spread of his Logic Conclusions (1598) and Theological Commentaries (1610) proves that Gil became a renowned philosopher and theologian. 
The case of the underestimated Gil reveals a common tendency displayed by superiors when filling out the catalogs. The seriousness of the task (improving the Society's organization) and the scientificity of the tool (the Galenic temperamental theory) did not suffice to avoid the discretional intromission of the superiors, who seem to have used this instrument in a political way, endorsing or hindering the career of the members they had to evaluate. That superiors used the choleric temperament when they intended to promote the Jesuit they were writing about is quite clear. Phlegmatic and sanguine temperaments were usually used to describe someone who should only be entrusted with minor or less worthy jobs, even though a sanguine temperament was sometimes added among the characteristics of a choleric Jesuit in order to soften his bilious traits.

The melancholic temperament was a real problem. Sometimes it was used in the sense of adust choler, which meant a saturnine temperament-that is, that the Jesuit was not obedient and probably eccentric, but also creative and quick-witted. The most important playwright of the Society in its first decades, Miguel Venegas (1531-c.91), for instance, was frequently described in this way. ${ }^{16}$ He was a notoriously troublesome man, but despite this, the Society never sought to dismiss him because his superiors recognized his great talent. At other times, however, a melancholic temperament indicated that the Jesuit was depressed, and thus unable to do anything. Consulting the catalogs can be a striking experience on this point: one will find a number of presumed depressed in the Society of Jesus. Yet it would appear that a "melancholic" label was also sometimes used to hide a conflict with the superior, thus revealing the superior's desire to denigrate or mar that particular Jesuit. Such was the case of José de Acosta (1539-160o), who was at odds with the general Claudio Acquaviva and had been accused of being depressed on a number of occasions. When a Jesuit was labeled as melancholic, his temperament was probably considered good for the Society as an organization, even though the Ratio studiorum would officially recommend to keep men of this temperament away from teaching.

Cholerics for leading and teaching, melancholics (adust choleric) for studying and inventing: these were the primary talents which the Society needed. Other temperaments were surely welcomed, but they were considered more suitable for cleaning up classrooms or providing supplies for the college. This is because, according to the Huartian method that the Jesuits applied in their catalogs, every kind of temperament fostered specific cognitive abilities and practical skills which allowed someone to succeed in doing only the jobs for which these skills were required. Like Huarte, the Jesuits also seemed to adopt

16 Luana Salvarani, "Venegas e gli altri. Il teatro nella prassi pedagogica gesuita del Cinquecento," Educazione: Giornale di pedagogia critica 1, no. 1 (2012): 53-72. 
a sort of radicalized Galenism, which narrowed the range of things an individual could be able to accomplish to the things he was suitable for.

\section{The Educative Side: Talents in the Ratio Studiorum}

While the Constitutions of the Society distinguished talents according to general tasks, such as ministries (preaching, confessing, and so forth) or roles (coadjutors, scholastics, professed), the Ratio studiorum specifically devoted several statements to the different skills required by each discipline. Indeed, the Constitutions referred to the general aim of studying, making no distinction between sciences and intellectual skills. In this respect, the Constitutions stressed the importance of self-examination by the individual who believed himself to be apt for studies. In giving an example of what should be asked of the aspiring scholastic in order to determine his aptness, the Constitutions emphasized the importance of the usual powers attributed to the rational soul as well as of characteristics Huarte himself would have considered vital:

So, that better knowledge and understanding of these candidates may be gained, these questions should be put to each one [...]. Does he think he has a memory to grasp and retain what he studies? Does he think that his intellect enables him to penetrate quickly and well what he studies? Does he find in himself a natural or voluntary inclination to studies? ${ }^{17}$

The Ratio studiorum softened the concept of the students' natural endowment by acknowledging the pedagogical importance of the arts and sciences for enhancing it. Yet the concept of the talent as a natural gift was of extreme relevance for shaping the educational course of each individual. ${ }^{18}$ The examination of the students was to be devoted not only to evaluating their commitment to each discipline but also to deepening the teachers' knowledge of their individual talent. For instance, if a student had completed the usual two years of rhetoric, but had shown a particular inclination for these kinds of studies, the Ratio recommended that the provincial should allow him to spend a further year studying rhetoric before being sent to study philosophy. ${ }^{19}$ The same went for those studying logic and the other philosophical disciplines.

\footnotetext{
17 Constitutions of the Society of Jesus, 47.

18 See Ratio studiorum's paragraphs 26 and 458 .

19 "If some are gifted with a special genius [ingenium] for substantial achievements, particularly in these studies [humanities and rhetoric], there ought to be some consideration of
} 
The examination of the talents was considered such a difficult task that it required particularly skilled examiners. The Ratio recommended that the provincial consult a commission of experts in order to make decisions about the future studies of the students. ${ }^{20}$ Furthermore, the Ratio clearly stated that each science or discipline corresponded to a different role in the Society to which the student could be entitled in the future. This meant that someone who was provided with the gift of a good intellect should be encouraged to continue his philosophical studies until theology. In contrast, those who showed less than an ordinary talent in reasoning should be sent to study cases of conscience. This discipline prepared the Jesuit to hear confessions, and it is curious that, as we have seen in the case of the aforementioned secret catalog, such an important ministry of the Society of Jesus was seen as suitable for the less gifted members. Nonetheless, the Ratio outlined a ranking of the intellectual tasks in the Society according to which preaching came first. This should not be a surprise, even though it was no more than one of the ministries that pertained to the general goal, stated in the Formula instituti, of helping souls.

In Huartian terms, an imaginative power ranked first in the Jesuit vision of their tasks. Someone who had a talent for preaching was allowed to study theology for four years, meaning that the student attended the courses offered by the Jesuits for the longest amount of time. Hence, completing the educational course after four years of theology was not a privilege of the intellectually talented, as one might fairly expect, but rather a possibility for those who, despite their lack of intellectual abilities, showed such a great imaginative talent as to promise to become great preachers or great leaders. The Ratio strictly followed Huarte's argument by stating that

if there were anyone who, to the extent that he was not entirely remarkable in his intellectual skills, was distinguished by such special personal virtue and capacity for leadership or preaching that he would likely compensate for that finished knowledge of theology asked for by the Constitutions, and if it were judged that the Society would benefit from the outcome if he completed the course of theology, then he could be

whether it might be worthwhile to invest three years in order to lay down a more solid foundation." The Ratio Studiorum: The Official Plan for Jesuit Education, trans. and annotated by Claude Pavur, S.J. (St. Louis: Institute of Jesuit Sources, 2005), 14.

20 Paragraph 36 addressed the problem of how a decision about talents should be made. The difficulty and seriousness of this task imposed upon the superior to "undertake a serious consideration with his consultors and with other men of character and influence who know them well and can make judgments about such matters." Ibid., 19. 
allowed a fourth year of theology, after the consultors have been informed of the matter. ${ }^{21}$

The character of a person was indeed worthy of great attention by the superiors. Although the Ratio did not use words such as "temperament" and "humor," one can fairly conclude that these concepts stood behind the description of the supposed bad attitudes of those philosophers the superior was allowed to expel: "If any professors are inclined towards innovations or have too freespirited an intelligence, they definitely ought to be removed."22

According to Huarte's theory, those who had a temperament that helped them in seeking innovations were called capricciosi ("capricious" - that is, melancholic) because of the adust choler. Of course, this kind of temperament could not find a place within the Ratio, a document whose principal aim was to help superiors with the complex task of governing colleges. This meant that extraordinary talents were simply not welcomed in the Jesuit colleges. Yet, as mentioned above, the Ratio was mostly a document that tried to mold what was really going on in the worldwide network of Jesuit colleges into a more uniform way of governing educational practices. Thus, the Ratio's advice to remove excessively innovative characters away from the philosophical chairs was more a symptom of the current situation than a general rule.

The same applied for the medical aspect of the temperamental theory used to examine the talents. Mental diseases were the dark side of melancholic students and teachers. The Constitutions had advised the Society to avoid admitting candidates who showed mental illnesses, whatever the concept of "mental illness" meant at that time. But, as we have seen before, melancholy stood precisely at the crossroads of what could be understood as a mental illness, spiritual disease, or great gift. ${ }^{23}$

Even though the Ratio did not explicitly address the issue, many indications were provided as to how superiors should take care of the students' bodies in order to avoid the spiritual troubles that result from an excessive commitment

\footnotetext{
21 Ibid., 17.

22 Ibid., 13.

23 I am grateful to Yasmin Haskell for her comments during the discussion that followed my presentation at the International Symposium on Jesuit Studies: Exploring Jesuit Distinctiveness (Boston, June 10-14, 2014). Concerning the history of the concept of melancholy among the Jesuits, see one of her articles, "Poetry or Pathology? Jesuit Hypochondria in Early Modern Naples," Early Science and Medicine 12 (2007): 187-213. She also informed me about a very promising project, which has been conducted by a research team from the University of Cambridge, about the history of the concept of genius before Romanticism: http://www.crassh.cam.ac.uk/programmes/genius-before-romanticism.
} 
to studying. One of the considerations that pushed the Ratio to keep men with an excessively unbalanced temperament away was the necessity of keeping the college's state of spiritual health as high as possible.

\section{Jesuit Literature on Skills}

Although the Jesuits had always been sensitive to the question of talents, Huarte's book represented a turning point for their collective self-perception. In fact, before the publication of the Examen, Jesuits who referred to a theory of human talents had to blend their intuition of others' temperaments with a non-systematic rhetorical tradition.

For instance, Benet Perera, in his two short treatises on education written while he was professor of philosophy at the Roman College (1564), ${ }^{24}$ assumed that talents and, generally speaking, the working of the mind, depend on the body's constitution. Yet he did not provide a precise connection between temperaments and the different skills with which someone could be endowed. This led him to use the term "wit" (ingenium) as referring to just one kind of human ability rather than as a category that pertained to all of the possible abilities:

To learn, the human soul needs the help of the wit, judgment, and memory. Regarding wit, one should observe keenness, swiftness, and skill. Regarding judgment, clearness, sharpness, and faculty of pondering, discerning, and distributing things are to be praised. Regarding memory, the power to easily understand and to keep learned things in mind for a long while is commended. Keenness of wit helps the logical power greatly, and in every kind of disputation. Clarity of judgment is very necessary in every part of philosophy and in all the gravest disciplines. Excellence of memory is required firstly in law, which one can advance very little in if endowed with less than a middling memory to learn it. ${ }^{25}$

In contrast, the Jesuits who wrote about talents after Huarte referred to his theory either to correct or to implement it through new observations and cases. They did not change the concept of talent as Huarte had defined it.

\footnotetext{
24 Benet Perera, "De modo legendi cursum philosophiae" and "Brevis ratio studendi," in Monumenta paedagogica Societatis Iesu, vol. 2: 1557-72, ed. László Lukács (Rome: Institutum Historicum Societatis Iesu, 1974), 664-69 and 670-85. 
When the Examen appeared for the first time in Italy (Venice 1575, translated by Camillo Camilli [?-1615]), Aldo Manuzio's bottega (publishing house) started to be crowded by scholars and intellectuals who wanted to respond to Huarte on the same topic. The first outcome was Manuzio's publication of Antonio Persio's (1543-1612) Trattato dello ingegno dell'huomo. Persio was a very close friend of the renowned philosopher Bernardino Telesio (1509-88), whose works he would later edit and publish. He tried to correct Huarte's theory according to Telesio's beliefs, in such a manner that the most relevant statement of Huarte (every man's nature is different) was substituted by the common Renaissance belief in a universal man.

Nonetheless, thanks to Possevino and Zara, the most important literature on this topic would receive a Jesuit mark. In his De cultura ingeniorum (1593), Possevino intended to correct Huarte's theory on the point of its materialistic determinism. According to Possevino, God provides each person with a different blend of physical constitution and mental skills. Yet every man receives from God the common gift of free will, through which he can seek his salvation by making good use of the talents he has. Furthermore, Possevino refers to both the humanistic (Giovanni Pico della Mirandola [1463-94] and Marsilio Ficino [1433-99]) and Platonic traditions in order to expand Huarte's explanation of the differences in talents among men. He states that, beyond temperament, social and historical features are at the origin of men's different characters and abilities.

Although Possevino intends these layers merely as an addition to Huarte's theory, they radically changed the Jesuit perspective on education. Possevino believes that even if someone is not naturally inclined to use memory or another one of the soul's powers, they can improve it by using their free willthat is, by choosing the best teachers, the best schools, and (basically) continuing to work hard. This does not mean that someone can reach the same level of quality by using their soul's weak power as can be attained by someone who is more naturally gifted. Yet Possevino believes that the examination of someone's skills is only the first step of a larger and deeper process of individual cultivation, which only a great school (or a great master) can provide, by planning a customized education based on an individual's skills.

In 1615, Antonio Zara published his Anatomia ingeniorum (The anatomy of talents), ${ }^{26}$ in which he set aside Possevino's concern about education to devote himself to cataloging men's intellectual skills in meticulous detail. His taste for taxonomy led him to add several causes to Possevino's list in order to explain

26 Antonio Zara, S.J., Anatomia ingeniorum et scientiarum sectionibus quattuor comprehensa (Venice: Ex typographia Ambrosij Dei, \& Fratrum, 1615). 
the differences between talents. Although his book's eighteen chapters seemed to multiply the causes that make people different from one another, Zara clearly adopted Huarte's temperamental theory (based on the Galenic quadripartion of humors) in order to distinguish between talents.

Even though the name of Huarte was forgotten during the seventeenth century, the Jesuits continued to use his theory. In Daniello Bartoli's (1608-85) Dell'uomo di lettere difeso et emendato (On the learned man defended and corrected, 1645), there is a lengthy digression on the concept of talent, interpreting it as cognitive skills based on one's specific temperament:

Since the tempera of the humors that serves the mind is not one and indivisible, the skills, talents, and genes, which incline people to different arts, derive from the variety of the humors. ${ }^{27}$

One can again find Huarte's influence in Giulio Cesare Becelli's (1686-1750) Trattato nuovo della divisione degli ingegni e studij secondo la vita attiva e contemplativa (A new treatise on the difference of talents and studies according to either the active or the contemplative life, 1738). ${ }^{28}$ In the introduction, Becelli recognized as his precursors some "excellently talented" modern men who had written about the nature of human talents. When he wrote this treatise, Becelli had already left the Society of Jesus and was teaching at the University of Padua. Yet his Jesuit inheritance is quite remarkably demonstrated by the fact that, among his works, two treatises directly echoed Possevino's masterpiecesnamely, the Trattato nuovo (The new treatise) and De bibliotheca instituenda ac ordinanda liber (A book on how to set up and organize a library).

\section{Conclusion}

In 1986, the International Commission on the Apostolate of Jesuit Education (ICAJE) published a document on the features of Jesuit educative activities that was in fact a manifest for the core values of Jesuit pedagogy. ${ }^{29}$ The second

27 Daniello Bartoli, S.J., Dell'huomo di lettere difeso et emendato: Parti due (Rome: Per gli heredi di Francesco Corbelletti, 1645).

28 Giulio Cesare Becelli, Trattato nuovo della divisione degli ingegni e studij secondo la vita attiva e contemplativa: Scritto singolarmente ad uso della nobiltà d'Italia (Verona: Per Dionisio Ramanzini, 1738).

29 The title of the document is "Ignatian Pedagogy: A Practical Approach." See International Commission on the Apostolate of Jesuit Education (ICAJE), "The Characteristics of Jesuit 
point of the document cited the cultivation of all of a student's talents as the main goal of Jesuit education. Significantly, this point listed four items, thereby specifying what the commission regarded as talents: the faculties of intelligence, imagination, sensitivity, and creativity; communication skills, which the document understood as the postmodern version of sixteenth-century eloquence; physical performance; and a good relationship with the community. Even though the historian should be careful in bridging different historical periods, the similarity to early modern Jesuit thought on talents and skills is striking. Furthermore, the document also recommends that the first goal of a good teacher should be to examine and be aware of the talents of each one of his students.

The discernment of skills is a key feature of the Jesuit identity today, even if the Galenic background seems to be merely a relic of the past. Nonetheless, that background was so important in shaping the way the Jesuits looked at themselves, their students, and the native peoples of the Indies that it stood as a hallmark of the Society as early as the sixteenth century. The Society's early documents pertaining to recruitment and organization reveal the particular Jesuit concern with examining the talents of both aspirants and fellows.

The influence of Juan Huarte de San Juan on this aspect of the Jesuit identity cannot be overestimated. According to Mauricio de Iriarte, S.J. (1894-?), this Spanish physician provided European psychology with a scientific concept, the concept of "talent," which could be applied in a wide range of human activities. ${ }^{30}$ Although no official document cites the name of Huarte, the Jesuits were among the first to take it seriously and apply it in their practices. They found in Huarte's method a practical way to respond to their concerns about effective recruitment and efficient organization, for it seemed to provide order to such a nuanced field as the relation between human temperaments and skills.

Of course, for a religious order, Huarte could be a troublesome companion because of his Galenic theory about men and souls. Possevino tried to correct Huarte's theory by reintroducing the concept of free will as human natural endowment, but he did not modify the core of Huarte's Galenism. Yet the problem posed by this kind of connection between human temperament and soul

Education," in The Jesuit Ratio studiorum: 4ooth Anniversary Perspectives, ed. Vincent J. Duminuco (New York: Fordham University Press, 1986), 161-230, and ICAJE, "Ignatian Pedagogy: A Practical Approach," in The Jesuit Ratio studiorum, 231-93.

30 Mauricio de Iriarte, S.J., Dr Juan Huarte de San Juan und sein Examen de ingenios: Ein Beitrag zur Geschichte der differentiellen Psychologie (Münster in Westfalen: Aschendorff, 1938). 
seemed to have been felt as unsolvable only by the philosophers of the Society, simply because they were involved in an environment which was shaped by Aristotle and his commentators, according to whom Galen was good as a physician but inconsistent as a philosopher.

It is for this reason that Manuel de Goís (1543-98), author of the many commentaries of the Jesuit Cursus conimbricensis, ${ }^{31}$ addressed the issue of "whether men's souls correspond to the temperaments" as a preliminary question in his De anima and concluded negatively. Remarkably, this question was quite unusual among the Scholastic commentaries of the sixteenth century, although in a paradoxical way it stands as a signpost of the Jesuits' peculiar interest in the theory of temperaments. Moreover, as the historian Marina Massimi points out, Manuel de Goís deals with the question of the relationship between talent and temperament in another passage of the same commentary, where he challenges Aristotle by demonstrating a clear relation between both choleric and melancholic temperaments and a swift intelligence. ${ }^{32}$ What pushed Manuel de Goís to contradict himself was surely his experience as a Jesuit and as a teacher. His acquaintance with the psychological insight he had to exercise in daily life burst from the apparently rigid Scholastic questions about the soul. He knew perfectly well what the Jesuits seem to have always known — that human souls are to be saved as well as sets of skills to be cultivated.

31 See Cristiano Casalini, Aristotele a Coimbra: Il Cursus conimbricensis e l'educazione al Collegium Artium (Rome: Anicia, 2012).

32 Marina Massimi, "Engenho e temperamentos nos catálogos e no pensamento da Companhia de Jesus nos séculos XVII e XVIII," Revista latinoamericana de psicopatologia fundamental 11, no. 4 (2008): 675-87. 